\title{
Effects of sewage sludge and its biochar on soybean yield in fine-textured loess soil
}

\author{
Hamed Fathi Dokht ${ }^{1^{*}}$, Seyed Alireza Movahedi Naeini ${ }^{2}$, Esmaeil Dordipour ${ }^{2}$, Liz Wollsene De Jong ${ }^{3}$, \\ Ebrahim Hezarjaribi ${ }^{4}$ \\ ${ }^{1} \mathrm{PhD}$ Student of Soil Science, Department of Soil Sciences, Gorgan University of Agricultural Sciences and Natural \\ Resources, Gorgan, Iran \\ ${ }^{2}$ Associate Professor of Soil Science, Department of Soil Sciences, Gorgan University of Agricultural Sciences and Natural \\ Resources, Gorgan, Iran \\ ${ }^{3}$ Professor of Soil Science, Department Agroecology, Aarhus University, Aarhus, Denmark \\ ${ }^{4}$ Research Instructor of Plant Breeding, Golestan Agricultural and Natural Resources Research Center, Gorgan, Iran
}

\begin{abstract}
Background: The application of biochar as a soil amendment has achieved popularity and has been found to improve considerably soil nutrient status and plant productivity in low fertile soils.

Methods: This study used two different methods to apply sewage sludge and sewage sludge biochar with three replicates in a completely randomized block design. The experiment included (1) control, (2) mulch biochar (20 t/ha), (3) incorporated biochar (20 t/ha), (4) mulch sewage sludge (45 t/ha), and (5) incorporated sewage sludge ( $45 \mathrm{t} / \mathrm{ha}$ ). This study aimed to investigate the potential benefits of sewage sludge and its biochar as mulch and incorporated into the top-soil for soil fertility, growth, yield, and shoot nutrient concentration of soybean and the effects of treatments on dry bulk density, water content, and mechanical resistance.

Results: The results showed higher values of height, biological yield, grain yield, and number of pods in the biochar mulch treatments $(116.5,10627.01,4180$, and 71.2 , respectively). Moreover, it was determined that the addition of biochar and sewage sludge to soil resulted in increased shoot nitrogen $(\mathrm{N})$, phosphorous $(\mathrm{P})$, and potassium $(\mathrm{K})$ concentrations, soil $\mathrm{P}$, soil $\mathrm{K}$, and total soil $\mathrm{N}(\mathrm{TN})$ compared with the control plots. Results from this study also showed that biochar and sewage sludge had positive impacts on the physical properties of soil. Bulk density and soil mechanical resistance were decreased, and volumetric water content was increased.

Conclusion: Heating sludge removed all pathogens. It is recommended that short- and long-term studies be conducted in the region to investigate further increases in the combined biochar and sewage sludge application rates.

Keywords: Nitrogen (N), Phosphorous (P), Potassium (K), Pathogens

Citation: Fathi Dokht H, Movahedi Naeini SA, Dordipour E, De Jong LW, Hezarjaribi E. Effects of sewage sludge and its biochar on soybean yield in fine-textured loess soil. Environmental Health Engineering and Management Journal 2017; 4(2): 83-91. doi: 10.15171/EHEM.2017.12.
\end{abstract}

Article History:

Received: 15 August 2016

Accepted: 15 January 2017 ePublished: 20 February 2017

\section{Introduction}

Soybean (Glycine max L. Merrill) originated in China where it has been cultivated since the 11th century. It was first grown in Iran in 1939. Soybean production in Iran has steadily increased from 6000 tons in 1970 to 1.5 million tons in 2007 (1). The use of organic and inorganic fertilizers can increase soil fertility. The main disadvantages of chemical fertilizers are their low availability to poor farmers (2) and soil degradation problems (3) resulting from the use of chemical fertilizers in consecutive years. Organic fertilizers are capable of modifying nutrient efficiency. Emphasis has to be placed on the use of organic fertilizer and microbial inoculants to ensure that agriculture remains a viable part of a healthy and sustainable ecosystem. Sewage sludge is a residual material from wastewater treatment process. Iran currently produces more than 25 million tons of sewage sludge (moisture of $80 \%$ ) in wastewater treatment plants, thereby creating a great environmental responsibility for plant owners and local officials (4). Biochar is a solid material gained from the thermo-chemical alteration (pyrolysis) of biomass in an oxygen-limited condition. It can be used for various purposes, such as a factor for soil enhancement, an enhancer of fertilizer use efficiency, protection against certain environmental pollutants, and as a way to reduce greenhouse gases (GHG) (5). The pyrolysis process is suitable for sludge management compared with the currently-used land filling, incineration, or direct agricultural utilization methods (5). The pyrolysis process can reduce the volume of sewage sludge, eradicate pathogens, and convert organic matter (OM) into biofuel, bio-oil, and biochar (6). Products of biochar from 
the sewage sludge produced through pyrolysis are rich in elemental carbon and nutrients and have plenty of exchangeable cations and surface adsorption sites which are very useful in eliminating pollutants from wastewater (7) and improving soil fertilization (8). Hence, biochar produced from sewage sludge through pyrolysis are of high interest. Biochar is charred OM considered for use as a soil modification. It is a fine-grained charcoal intended for use in both ameliorating the physical, chemical, and biological properties of soil and sequestering soil carbon (9). Products generated in the pyrolysis process include biochar, gas, and liquid. Differences in ratios are caused by the type of OM and temperature (10). Though different biochars share the basic characteristics (e.g., high $\mathrm{C}$ content), all of them have different particular characteristics related to the properties of the raw organic materials (feedstock) and the pyrolysis parameters used for production (11). Biochar has the valuable ability to retain water and nutrients. Moreover, the material offers a conductive habitat for soil microorganisms and, thus, can contribute to soil fertility (12). Biochar can also be used to improve water retention in farmlands, reduce nitrous oxide emissions, balance soil acidity, and increase soil organic carbon (13). Sewage sludge and its biochar have the potential for use as a fertilizer in agricultural production to resolve the needs of plants. Total and available phosphorous $(\mathrm{P})$ and potassium $(\mathrm{K})$ concentrations were increased by the pyrolysis process, although those of total and available $\mathrm{N}$ were decreased. Adding sewage sludge biochar to non-fertile and contaminated soils increased the fresh matter weight of Chinese cabbage (14). In addition, organic waste applied as mulch or incorporated in the topsoil affected the physical properties of soil and plant growth (15), which, in turn, contributed to higher crop yield.

Iran's agriculture makes heavy use of farm chemicals which can adversely affect soil quality, the environment, and human health while increasing production costs. However, sewage sludge (biomass) can be converted on the farm to produce biochar, which can contribute to improving soil quality and increasing yield. In the long term, this method of soil amelioration can contribute to more sustainable farming. The goals of this study were: 1) to assess the potential benefits of sewage sledge and its biochar as mulch incorporated into topsoil for soil fertility, growth, and yield of soybean; and 2) to determine the impact of sewage sludge and its biochar as mulch incorporated into topsoil on dry bulk density, water content, and mechanical resistance.

\section{Material and Methods}

Description of the study area

Field trials were conducted at Gorgan University of
Agricultural Sciences and Natural Resources, Golestan province, Iran (approx. $37^{\circ} 45^{\prime} \mathrm{N}, 54^{\circ} 30^{\prime} \mathrm{E}$; altitude $13 \mathrm{~m}$ A.S.L.). The average annual rainfall there was $607 \mathrm{~mm}$ and mean air temperatures were $13.5^{\circ} \mathrm{C}$ from 2005 to 2015 . Sewage sludge and sewage sludge biochar were applied on June 3, 2014.

\section{Collection of soil samples}

Composite soil samples were taken from a depth of 0-30 cm before the experiments. The soil samples were taken to the laboratory, air-dried, and passed through a 2-mm sieve. $\mathrm{pH}$ and electrical conductivity (EC) were determined in a 1:2.5 $(\mathrm{g} / \mathrm{mL})$ soil: water ratio using a pH meter (Mettler Toledo Delta 320) (16) and EC meter (DDS-307A) (17), respectively. Cation exchange capacity (CEC) was determined using $\mathrm{NH}_{4} \mathrm{OAc} / \mathrm{NaNH}_{4} \mathrm{OAc}$ at 7.0 (18). OM was determined with the Walkley-Black method (19). Calcium carbonate equivalent (CCE) was measured by acid neutralization (20). Total nitrogen (TN) was determined with the Kjeldhahl method, and available phosphorous (P) according to Olsen method (21). The available potassium (AK) was extracted from saturated paste by vacuum pump and analyzed by flame emission spectrophotometry. Finally, soil texture was determined using the Bouyoucos method (22). All analyses were performed in parallel and in triplicate, and the results are listed in Table 1.

\section{Sewage sludge preparation and characteristics}

Sludge used for the pyrolysis treatment in this study was collected from the Kordkuy sewage sludge treatment plant (Golestan province, Iran). Biochar was produced by pyrolyzing the biomass at various temperatures under $\mathrm{O}_{2}$-limited conditions. Dried sewage sludge was collected from Gorgan, and the sewage sludge was pyrolyzed in a closed ceramic pot under $\mathrm{O}_{2}$-limited conditions at $350^{\circ} \mathrm{C}$ for 3 hours $(23,24)$. The $\mathrm{pH}, \mathrm{EC}$, and $\mathrm{CEC}$ of the biochar and sewage sludge were determined and analyzed with the same methods as mentioned above for soil testing. The yield of biochar was determined as follows:

Biochar yield $(\%)=\left(\mathrm{W}_{2} / \mathrm{W}_{1}\right) * 100$ where $W_{1}$ is the dry weight of the sewage sludge sample prior to pyrolysis and $\mathrm{W}_{2}$ is the biochar weight. The biochar yield was calculated by subtracting the chemical reagent weight from the biochar mass produced.

Ash was separated by placing the biochar or sewage sludge sample in a nickel crucible and heating it at $700^{\circ} \mathrm{C}$ for 2 hours under air (25). The ash content was calculated as follows:

Ash content $(\%)=(\mathrm{M} \mathrm{Ash} / \mathrm{M}$ Biochar or sewage slud ge) $* 100$

where $\mathrm{M}$ Ash was the mass of ash and $\mathrm{M}$ Biochar or sewage sludge was the mass of biochar or sewage sludge.

Table 1. Main characteristics of studied soils

\begin{tabular}{|c|c|c|c|c|c|c|c|c|c|}
\hline $\mathrm{pH}$ & $\mathrm{EC}\left(\mathrm{dS} \mathrm{m}^{-1}\right)$ & $\operatorname{CEC}\left(\mathrm{cmol}^{+} \mathrm{kg}^{-1}\right)$ & Clay $\mathbf{g} \mathbf{~ k g}^{-1}$ & Silt $\mathbf{~ g ~ k g}^{-1}$ & Sand $\mathbf{g ~ k g}^{-1}$ & OM (\%) & TN (\%) & $\mathrm{K} \mathrm{mg} / \mathrm{kg}$ & $\mathrm{P} \mathrm{mg} / \mathrm{kg}$ \\
\hline 7.8 & 0.88 & 20 & 339 & 461 & 200 & 1.6 & 0.09 & 245 & 9.8 \\
\hline
\end{tabular}


Table 2. Basic characterization of sewage sludge and biochar pyrolyzed at $350^{\circ} \mathrm{C}$

\begin{tabular}{lllllllll}
\hline Treatments & Moisture (\%) & Yield (\%) & Hydrophobicity & Ash (\%) & pH & EC dSm & CEC cmol $^{(+)}\left(\mathrm{kg}^{-1}\right)$ & ${\text { BET surface area }\left(m^{2} / g\right)}^{\prime}$ \\
\hline Sewage sludge & 84.1 & - & - & 44.45 & 6.3 & 4.2 & 23.1 & 1.1 \\
Biochar $\left(350^{\circ} \mathrm{C}\right)$ & - & 48.1 & Hydrophilic & 60.2 & 7.9 & 2.4 & 21.2 & 34.2 \\
\hline
\end{tabular}

Finally, the surface area of the biochar and sewage sludge was measured using the Brunauer, Emmett and Teller (BET) method that measured N2 gas sorption $(0.162$ $\mathrm{nm}^{2}$ ) at $77 \mathrm{~K}$. Approximately $200 \mathrm{mg}$ of ground biochar was outgassed at $120^{\circ} \mathrm{C}$ for 16.5 hours and then analyzed on an Autosorb-1 Surface Area Analyzer (Quantachrome Instruments). Five data points with relative pressures of $0.05-0.3$ were used to calculate the surface area (26). Hydrophobicity was measured using the ethanol droplet test (27). All analyses were performed in triplicate and in parallel, and results are listed in Table 2.

\section{Moisture content}

Based on ASTM D2216-98 (28), the moisture content was determined by oven drying sewage sludge at $110^{\circ} \mathrm{C}$ until constant weight.

Determination of heavy metal content in sludge and biochar

Aqua regia (mixture of $\mathrm{HF}, \mathrm{HClO}_{4}, \mathrm{HNO}_{3}$, and $\mathrm{H}_{2} \mathrm{SO}_{4}$ acids in the same ratio) was used to determine the total content of heavy metals (29). The heavy metal content of the digestate was then measured with an atomic absorption spectrophotometer equipped with a graphite furnace (Analytik Jena, AAS6 Vario). This experiment determined the $\mathrm{Cd}, \mathrm{Cu}, \mathrm{Ni}, \mathrm{Pb}, \mathrm{Cr}, \mathrm{Co}$, and As contents of sludge and biochar.

Sewage sludge and sewage sludge biochar agronomic properties

Total carbon (c), nitrogen $(\mathrm{N})$, hydrogen $(\mathrm{H})$, and oxygen (O) contents of sewage sludge and biochar were determined using an EA3000 Element Analyzer (Euro Vector, Italy). Total phosphorus (TP) and available phosphorous (AP) contents were determined by molybdenum antimony colorimetry. Total potassium (TK) and AK contents were determined by flame emission spectrometry. Hydrolysable nitrogen (HN) content was determined by alkaline hydrolysis and distillation.

\section{Preparation of experimental plots}

The experiment was a completely randomized block design with three replicates conducted on $2 \mathrm{~m} \times 3 \mathrm{~m}$ experimental plots ploughed to a depth of $30 \mathrm{~cm}$. The soil surface was pulverized and raked even. Levees were constructed to separate the plots. In this experiment, treatment 1 (T1) was the untreated control, treatment 2 (T2) was soil with mulch biochar at $20 \mathrm{t} / \mathrm{ha}$, treatment 3 (T3) was soil with incorporated sewage sludge biochar at $20 \mathrm{t} / \mathrm{ha}$, treatment 4 (T4) was soil with mulch sewage sludge (dry weight) at $45 \mathrm{t} / \mathrm{ha}$, and treatment 5 (T5) was soil with incorporated sewage sludge (dry weight) at $45 \mathrm{t} /$ ha (Figure 1). Each treatment consisted of 5 sub-treatments of chemical fertilizer (ST): ST1 (0 kg/ha), ST2 (N (100 kg/ha)), ST3 (N (100 kg/ha) and P (50 kg/ha)), ST4 (N (100 kg/ha) and K (300 kg/ha)), and ST5 (N (100 kg/ha), K (300 kg/ha), and $\mathrm{P}(50 \mathrm{~kg} / \mathrm{ha})$ ) (Figure 1). Fertilizer sources for N, P, and K were urea, triple superphosphate, and $\mathrm{K}$ sulfate.

The land was ploughed and disked before any treatments were applied. For the mulch treatments, the sewage sludge biochar and sewage sludge were applied uniformly over the land instantly after sowing manually. Where the sewage sludge biochar and sewage sludge were to be incorporated (T3 and T5), it was initially applied uniformly as mulch and then incorporated to a depth of $0.2 \mathrm{~m}$ manually using a spade before drilling. To determine the appropriate amount of biochar application rates, previous studies were reviewed. The application amount used in previous studies varied widely from below $5 \mathrm{t} /$ ha to over $100 \mathrm{t} / \mathrm{ha}$. Results of previous studies indicated that a rate in the range of $5 \mathrm{t} /$ ha to $20 \mathrm{t} /$ ha is appropriate for agricultural crops, though the appropriate rate depends on various factors such as primary soil characteristics and type of crop being grown. The application of sludge was 2.25 times greater than that of biochar based on the sludge-to-biochar conversion yield.

\section{Crop cultivation}

The soybean variety used in this experiment was D.P.X3589. Each plot was sub-divided into rows with an inter-row distance of $30 \mathrm{~cm}$ and $15 \mathrm{~cm}$ between
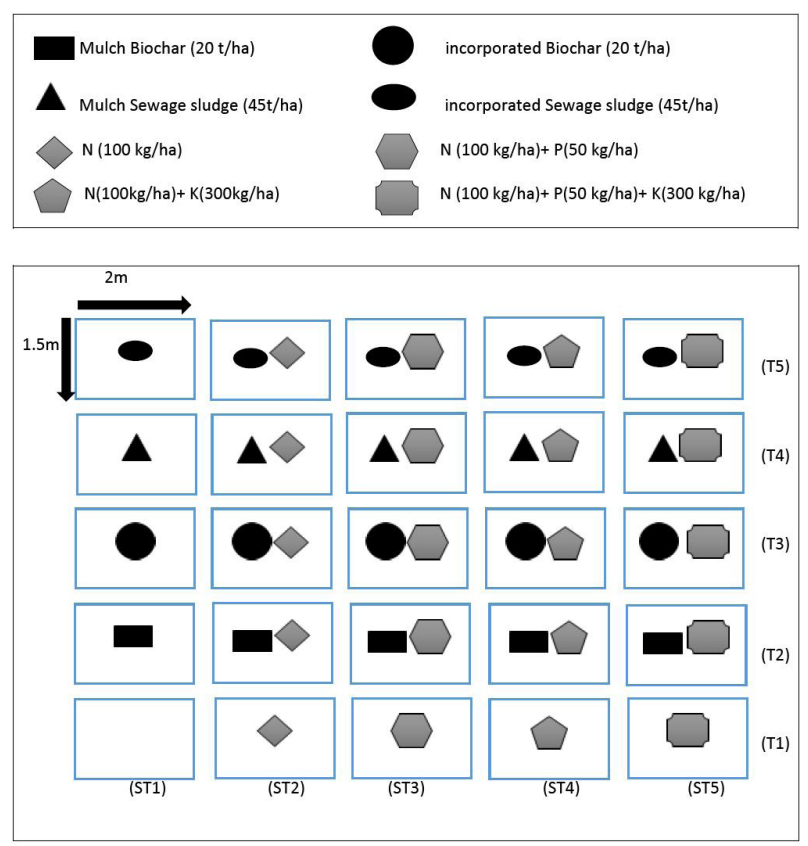

Figure 1. Field trial layout showing treatments 
planting holes. Six seeds were planted in each hole. After seedling emergence, 3 seedlings were removed, leaving the strongest three remaining in each hole. Weeds were regularly removed by hand-weeding after planting. Based on soil moisture content, the irrigation interval was generally 20 to 25 days in the first stages of plant growth; in summer, irrigation intervals of 10-15 days were applied.

\section{Measurements}

Plant height per plant $(\mathrm{cm})$ : Plant height was measured from the base to the top with the aid of a measuring tape at the end of cropping.

Number of pods per plant: All pods of the plants were harvested and counted.

Grain yield ( $\mathrm{kg} / \mathrm{ha}$ ) and biomass $(\mathrm{kg} / \mathrm{ha})$ : At maturity, all pods were harvested, all grains were recovered after shelling, and then they were weighed using top load balance (with a basin-like top and calibrated in $\mathrm{kg}$ ) per plot. The grain yield per hectare was determined as follows:

Grain Yield $(\mathrm{kg} / \mathrm{ha})$ and biomass $(\mathrm{kg} / \mathrm{ha})=($ Grain Yield (kg/ha) or biomass $\left.(\mathrm{kg} / \mathrm{ha})^{*} 10000 \mathrm{~m}^{2}\right) /$ Plot Area $\left(\mathrm{m}^{2}\right)$

Soil physical properties: Volumetric water content was determined gravimetrically on soil cores for depths of $0-0.08 \mathrm{~m}$ at 6 times (M1, M2,.., M6) by oven drying. On the same dates, mechanical resistance was measured in the field with a portable cone penetrometer $(\mathrm{S} 1, \mathrm{~S} 2, \ldots$, S6). Dry bulk density samples were collected using a standard core sampler with a sampling volume of 100.8 $\mathrm{cm} 3$ at 6 times $(\mathrm{Bd} 1, \mathrm{Bd} 2, \ldots, \mathrm{Bd} 6)$ for each treatment and all replicates according to the core method. Samples were collected at depths of $0-08 \mathrm{~cm}$ and oven dried for approximately 24 hours at $105^{\circ} \mathrm{C}$ to a constant mass. Soil bulk density was determined (equation 2 ) by dividing the known mass of soil by the soil volume it occupied: $\rho \mathrm{b}=$ soil mass / volume occupied by soil sample where soil was measured in grams and volume in $\mathrm{cm}^{3}$. Tissue nutrient concentration: $\mathrm{N}, \mathrm{P}$, and $\mathrm{K}$ contents in plant shoot material at flowering were determined using a standard digest technique (30). $\mathrm{N}$ was measured using Kjeltec, P using a colorimetric method, and $\mathrm{K}$ by flame photometry. Plant shoot samples were selected at random from the center of each plot between two adjacent rows on July 10, 2015 in three replicates per plot and mixed.

Soil chemical properties: Available P (from a sodium bicarbonate extractant), $\mathrm{K}$ (using a $1 \mathrm{~N} \quad \mathrm{NH}_{4} \mathrm{OAc}$ extractant), and soil TN (using a K chloride extractant) contents were determined at harvest. Soil samples were selected at random from the center of each plot between 2 adjacent rows at depths of 0 to $0.2 \mathrm{~m}$ on October 20, 2014 in 3 replicates per plot and mixed.

Statistical analysis

The data collected from this experiment was analyzed and compared for statistical differences using the Analysis of Variance (ANOVA) method and Duncan's new multiple range test (DMRT), and the software package Statistical Package for the Social Sciences (SAS) was used to process the analyses.

\section{Results and Discussion}

Sewage sludge and biochar characterization

The sewage sludge and biochar properties, including yield, ash content, $\mathrm{pH}, \mathrm{CEC}$, moisture, hydrophobicity, EC, and BET, are summarized in Table 2. The yield of biochar produced at $350^{\circ} \mathrm{C}$ was $48.1 \%$, which was in accordance with the result obtained by Méndez et al (24). The pyrolysis process increased the percentage of ash content, as reported by others $(31,32)$. The percentage of ash content was increased from $59.45 \%$ for sewage sludge to $64.2 \%$ for biochar. Pyrolysis also increased $\mathrm{pH}$ as results of polymerization/condensation reactions and acidic surface groups released during pyrolysis showed (24). The EC, a factor used to evaluate the content of total dissolved salts in a sample, was $4.2 \mathrm{dSm}^{-1}$ for sewage sludge; this figure declined with pyrolysis to $2.4 \mathrm{dSm}^{-1}$ for biochar at $350^{\circ} \mathrm{C}(24)$. The CEC value decreased with the pyrolysis temperature from $23.1 \mathrm{cmol}^{(+)} \mathrm{kg}^{-1}$ for sewage sludge to 21.2 for biochar at $350^{\circ} \mathrm{C}$. These results are in agreement with those obtained by Méndez et al (24). The declines in CEC with the pyrolysis process may be due to functional groups released within the pyrolysis process (24). SSA, one of the main factors in evaluating adsorption, is involved in the distribution of pore structure (33). The results showed that the BET surface area of biochar increased during the pyrolysis process, as reported by others $(24,34)$. The BET surface area of the biochar obtained at $350^{\circ} \mathrm{C}\left(34.2 \mathrm{~m}^{2} / \mathrm{g}\right)$ was larger than that of sewage sludge $\left(1.1 \mathrm{~m}^{2} / \mathrm{g}\right)$.

Heavy metal contents of sewage sludge and biochar Table 3 presents the heavy metal contents of sewage sludge and biochar. Within wastewater treatments, nearly $50 \%$ to $80 \%$ of the heavy metal content present in wastewater is preserved in the sewage sludge; this clarifies the high concentration of particular metals in sewage sludge (35). In this study, the heavy metal content was not as high and did not exceed the EPA thresholds for sewage sludge land usage (values in bold letters in Table 3) (36).

Table 3. Heavy metal analysis of the sewage sludge and biochars

\begin{tabular}{|c|c|c|c|c|c|c|c|}
\hline \multirow{2}{*}{ Treatment } & \multicolumn{7}{|c|}{ Heavy metal (mg/kg) } \\
\hline & $\mathrm{Cd}$ & $\mathrm{Cu}$ & $\mathrm{Ni}$ & $\mathrm{Pb}$ & $\mathrm{Pb}$ & As & Co \\
\hline Sewage sludge & 2.1 & 54.2 & 61 & 91 & 28.3 & $\mathrm{BDL}$ & $\mathrm{BDL}$ \\
\hline Biochar $\left(350^{\circ} \mathrm{C}\right)$ & 3.8 & 98 & 112 & 158 & 52 & $\mathrm{BDL}$ & $\mathrm{BDL}$ \\
\hline US EPA, 1993 & 85 & 4300 & 420 & 840 & 3000 & 75 & 50 \\
\hline
\end{tabular}

Abbreviation: BDI, below detection limit. 
Table 4. Agronomic properties of sewage sludge and sewage sludge biochar

\begin{tabular}{|c|c|c|c|c|c|c|c|c|c|}
\hline Treatment & $\mathrm{C}(\%)$ & $\mathrm{O}(\%)$ & H (\%) & $\mathbf{N}(\%)$ & $\mathrm{TP} \mathrm{g} / \mathrm{kg}$ & TK g/kg & $\mathrm{HN} \mathrm{g} / \mathrm{kg}$ & $\mathrm{AP} \mathrm{g} / \mathrm{kg}$ & $\mathrm{AK} \mathrm{g} / \mathrm{kg}$ \\
\hline Dried sewage sludge & 25.2 & 19.48 & 5.1 & 5.7 & 8.5 & 7 & 0.18 & 0.3 & 1.8 \\
\hline Biochar $\left(350^{\circ} \mathrm{C}\right)$ & 26.4 & 8.30 & 1.1 & 3.9 & 14 & 12.2 & 0.05 & 1.1 & 2.1 \\
\hline
\end{tabular}

Sewage sludge and sewage sludge biochar agronomic properties

Pyrolysis process factors like temperature, residence time, and heating rate can affect the quality and quantity specifications of biochar (37). In the current study, sewage sludge was changed at a relatively low pyrolysis temperature $\left(350^{\circ} \mathrm{C}\right)$, allowing for biochar that is suitable for agricultural uses (38). The elemental content changes in $\mathrm{C}, \mathrm{H}, \mathrm{O}$, and $\mathrm{N}$ are also listed in Table 4 . As expected in the pyrolysis process for the biochar, the $\mathrm{C}$ content increased, while the $\mathrm{H}, \mathrm{N}$, and $\mathrm{O}$ contents decreased. Temperature can increase the carbon content, possibly due to the increasing degree of carbonization. However, the decreases in $\mathrm{O}$ and $\mathrm{H}$ elements could be attributed to the breaking of weaker bonds in the biochar structure and the highly carbonaceous materials yielded with increased temperature. This fact was also suggested by results obtained by other authors (33). The contents of major plant nutrients $\mathrm{N}, \mathrm{P}$, and $\mathrm{K}$ were determined to assess whether biochar was a favorable fertilizer for agricultural land. $\mathrm{N}$ and $\mathrm{HN}(0.05 \%)$ contents of biochar were lower than those of dried sewage sludge on the grounds of the volatilization of $\mathrm{N}$ within pyrolysis. $\mathrm{N}$ can be removed through the losses of $\mathrm{NH}_{4}-\mathrm{N}$ and $\mathrm{NO}_{3}-\mathrm{N}$ fractions as well as volatile matter containing $\mathrm{N}$ groups at $200^{\circ} \mathrm{C}(9,39)$. Nonetheless, the accessibility of $\mathrm{N}$ in biochar remains unclarified (33). The TP and K contents of biochar were increased by $64.5 \%$ and $74.1 \%$, respectively.

1000-grain weight, grain yield, biological yield, plant height, and number of pods per plant

As shown in Tables 5 and 6, the sewage sludge, its biochar and chemical fertilizer had a significant effect on 1000-grain weight, grain yield, biological yield, plant height, and number of pods per plant. The highest values of 1000-grain weight, grain yield, biological yield, plant height, and number of pods per plant were found in mulch biochar (T2) (230.1 g, $4182 \mathrm{~kg} \mathrm{ha}^{-1}, 10627 \mathrm{~kg} \mathrm{ha}^{-1}$, $116.53 \mathrm{~cm}$, and 71.2 , respectively), and the lowest values were observed in the control treatment (T1) (155.4 g, 2086 $\mathrm{kg} \mathrm{ha}^{-1}, 8117 \mathrm{~kg} \mathrm{ha}^{-1}, 92.2 \mathrm{~cm}$, and 36.2, respectively). In the chemical fertilizer treatment (ST), the highest values of 1000-grain weight, grain yield, biological yield, plant height, and number of pods per plant were found in NPK (ST5) $\left(220.76 \mathrm{~g}, 3821.47 \mathrm{~kg} \mathrm{ha}^{-1}, 10421.2 \mathrm{~kg} \mathrm{ha}^{-1}, 114.4\right.$ $\mathrm{cm}$, and 66.13 , respectively), and the lowest values were observed in the control treatment (ST1) (201.82 g, 3148.7 $\mathrm{kg} \mathrm{ha}^{-1}, 9343.6 \mathrm{~kg} \mathrm{ha}^{-1}, 103.3 \mathrm{~cm}$, and 57.64, respectively). Yamika and Ikawati reported that the values of 1000-grain weight, grain yield, biological yield, plant height, and number of pods per plant were increased in soybean with the addition of biochar in soils (40). Moreover, Yooyen et al reported that the combination of inorganic and organic fertilizers $\left(0,0.5\right.$, and $\left.1 \mathrm{t} \mathrm{ha}^{-1}\right)$ increased seed yield up to $3.5 \mathrm{t} \mathrm{ha}^{-1}$, which was closely similar to this experiment (41). Navin et al also showed that adding biochar to soil can increase soybean yield (42). Falodun et al (43)and Liang et al (44) showed that plant height was increased by organic and inorganic fertilizers.

Effects of biochar and sewage sludge on some soil physical properties

Biochar and sewage sludge have the potential to modify the physical condition of soil, including factors such as surface area, pore size distribution, bulk density, waterholding capacity, and soil mechanical resistance (45).

Dry bulk density for depths of $0.0-0.08 \mathrm{~m}$ during the growing season

Differences in dry bulk density among treatments

Table 5. Effects of treatment applications on average soybean yield

\begin{tabular}{|c|c|c|c|c|c|}
\hline Treatment & $\begin{array}{l}\text { 1000-grain weight } \\
\text { (g) }\end{array}$ & $\begin{array}{l}\text { Number of pods } \\
\text { per plant }\end{array}$ & $\begin{array}{l}\text { Plant height } \\
\text { (cm) }\end{array}$ & $\begin{array}{l}\text { Grain yield } \\
(\mathrm{kg} / \mathrm{ha})\end{array}$ & $\begin{array}{l}\text { Biological yield } \\
\text { (kg/ha) }\end{array}$ \\
\hline \multicolumn{6}{|c|}{ Factor (A) (biochar and sewage sludge $\mathrm{T1}, \ldots, \mathrm{T} 5$ ) } \\
\hline Control (T1) & $155.41^{c}$ & $36.2^{\mathrm{c}}$ & $92.2^{c}$ & $2086.47^{c}$ & $8117.62^{d}$ \\
\hline Biochar mulch (T2) & $230.1^{\mathrm{a}}$ & $71.2^{\mathrm{a}}$ & $116.53^{\mathrm{a}}$ & $4182.73^{\mathrm{a}}$ & $10627.01^{\mathrm{a}}$ \\
\hline Biochar incorporation (Т3) & $227.6^{\mathrm{ab}}$ & $70.73^{a}$ & $115.53^{\mathrm{a}}$ & $4055.8^{\mathrm{a}}$ & $10528.6^{\mathrm{a}}$ \\
\hline Sewage sludge mulch(T4) & $225.98^{\mathrm{ab}}$ & $66.2^{\mathrm{b}}$ & $112.46^{b}$ & $3714.00^{b}$ & $10160.8^{b}$ \\
\hline Sewage sludge incorporation (T5) & $220.44^{b}$ & $65.13^{\mathrm{b}}$ & $111.87^{\mathrm{b}}$ & $3612.73^{b}$ & $9979.3^{c}$ \\
\hline \multicolumn{6}{|c|}{ Factor (B) (chemical fertilizer ST1, ...,ST5) } \\
\hline NPK (ST5) & $220.76^{a}$ & $66.13^{\mathrm{a}}$ & $114.4^{\mathrm{a}}$ & $3822.93^{a}$ & $10421.2^{\mathrm{a}}$ \\
\hline NK (ST4) & $216.51^{\mathrm{a}}$ & $63.46^{\mathrm{b}}$ & $110^{\mathrm{b}}$ & $3689.53^{b}$ & $10001.8^{b}$ \\
\hline NP (ST3) & $211.73^{b}$ & $62^{\mathrm{bc}}$ & $112.86^{\mathrm{a}}$ & $3580.67^{c}$ & $9938.51^{b c}$ \\
\hline $\mathrm{N}(\mathrm{ST} 2)$ & $208.84^{b}$ & $60.4^{c}$ & $108^{b}$ & $3390.33^{d}$ & $9753.2^{c}$ \\
\hline Control (ST1) & $201.82^{c}$ & $57.64^{d}$ & $103.3^{c}$ & $3147.87^{e}$ & $9343.6^{d}$ \\
\hline
\end{tabular}


Table 6. Analysis of Variance on average soybean yield

\begin{tabular}{|c|c|c|c|c|c|c|}
\hline \multirow[b]{2}{*}{ Sources of variances } & \multirow[b]{2}{*}{$\begin{array}{l}\text { Degree of } \\
\text { freedom }\end{array}$} & \multicolumn{5}{|c|}{ Means of squares } \\
\hline & & $\begin{array}{c}\text { 1000-grain weight } \\
\text { (g) }\end{array}$ & $\begin{array}{l}\text { Number of pods } \\
\text { per plant }\end{array}$ & $\begin{array}{l}\text { Plant height } \\
\text { (cm) }\end{array}$ & $\begin{array}{c}\text { Grain yield } \\
\text { (kg/ha) }\end{array}$ & $\begin{array}{c}\text { Biological yield } \\
\text { (kg/ha) }\end{array}$ \\
\hline Replications & 2 & 463.1 & 0.89 & 3.72 & 47902.45 & 25080 \\
\hline Factor A (biochar and sewage sludge) & 4 & $15166.9^{\text {;** }}$ & 3202.32 & $1497.44^{* *}$ & $10505373^{\text {s.*. }}$ & $15908765.6^{\text {*** }}$ \\
\hline Error A & 8 & 120.3 & 10.81 & 9.78 & 20450.6 & 37355.8 \\
\hline Factor B (chemical fertilizer) & 4 & $789.7^{* *}$ & $158.58^{* * *}$ & $283.6^{* *}$ & $1045790.2^{* * s}$ & $2303761.5^{\text {**⿻ }}$ \\
\hline Error B & - & 39.7 & 12.09 & 8.32 & 26055 & 67272 \\
\hline$A \times B$ & 16 & 18.08 & 1.34 & 17.01 & 14212.5 & 104051.1 \\
\hline CV & - & 2.9 & 5.6 & 2.62 & 4.57 & 2.62 \\
\hline
\end{tabular}

**Significant at the 0.01 level; *Significant at the 0.05 level.

were significant as determined by ANOVA for the 6 measurement dates (Bd1, Bd2,.., Bd6). Dry bulk density values within 0.0 to $0.08 \mathrm{~m}$ with mulch applications (T2 and T4) and incorporation treatments (T3 and T5) were still lower than the control (T1) during the growing season (at all measurement dates), irrespective of the statistics (Figure 2). Chan and Xu reported that bulk density in top soil was decreased with the addition of biochar to soils (11). Moreover, Jones et al (46) showed that OM reduced bulk density by soil dilation and improvement in aggregate stability. The decrease in bulk density in the biochar and OM-amended soils might be caused by the physical dilution effects, as reported by Jones et al, who showed that increasing OM content can significantly decrease bulk density. In addition, the application of biochar decreased soil dry bulk density (45). It can lead to alterations in soil aggregate sizes, as shown by Jones et al (46) and MacRae and Mehuys (45). No difference in soil dry bulk density was seen among sub-treatments.

Volumetric soil water content for depths of 0-0.08 m during growing season

ANOVA results showed differences between treatments for the volumetric water content in soil within the growing season were significant. The biochar mulch application (T2) significantly increased the volumetric water content in soil relative to other treatments during the growing season. The water content of soil for mulch biochar (T2), incorporation biochar(T3), incorporation sewage sludge (T5), and mulch sewage sludge (T4) were significantly greater than the control(T1) (Figure 3). Relative to incorporation treatments (T3 and T5), the effect of mulch treatments (T2 and T4) on soil volumetric water content became more pronounced at the growing season, especially when the evaporation potential was high. Asai et al (47) and Chan et al (48) indicated that applying biochar to soil can improve water-holding capacity and water retention which may be a factor in both yield improvement and plant nutrient availability. Jones et al showed that sewage sludge, because of its high OM content, significantly increased the volumetric water content of soil in treatments (46). Moreover, soil water content rates among sub-treatments were not different.

Soil Mechanical Resistance during Growing Season Differences among treatments for soil mechanical resistance were significant for all measurements as shown by analysis of variance. Soil mechanical resistance in both incorporation (T3 and T5) and mulch (T2 and T4) treatments was significantly less than the control (T1) during the growing season (Figure 4). Soil mechanical resistance with biochar mulch (T2) was significantly less than the other treatments at the end of the growing season. Gantzer et al reported a decrease in soil

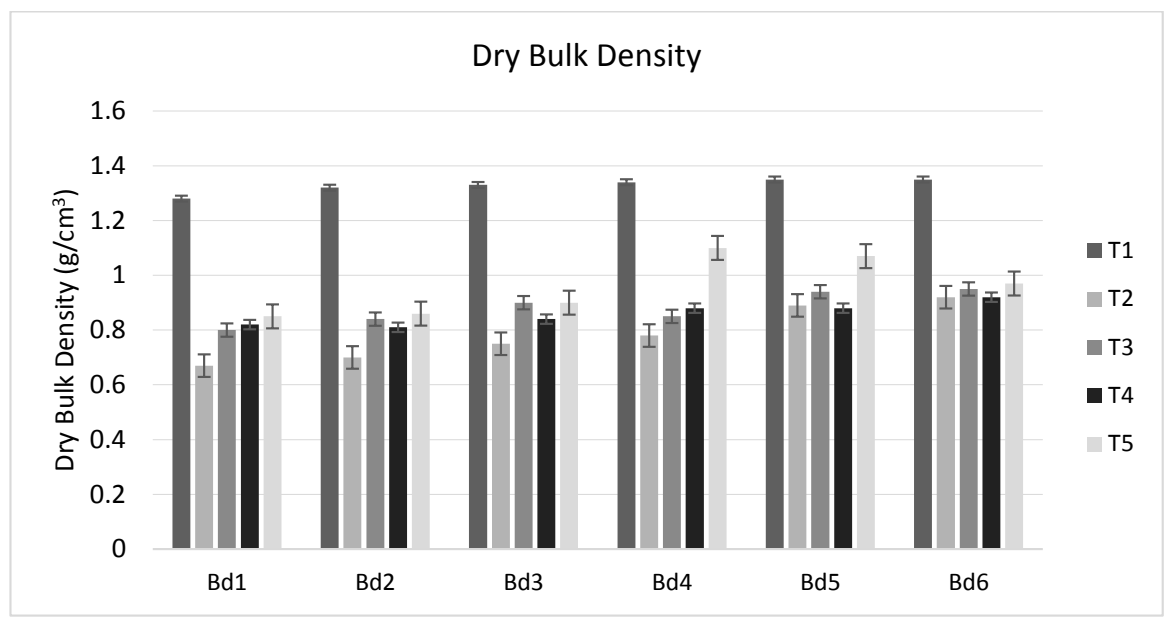

Figure 2. Influence of biochar and sewage sludge on dry bulk density. 


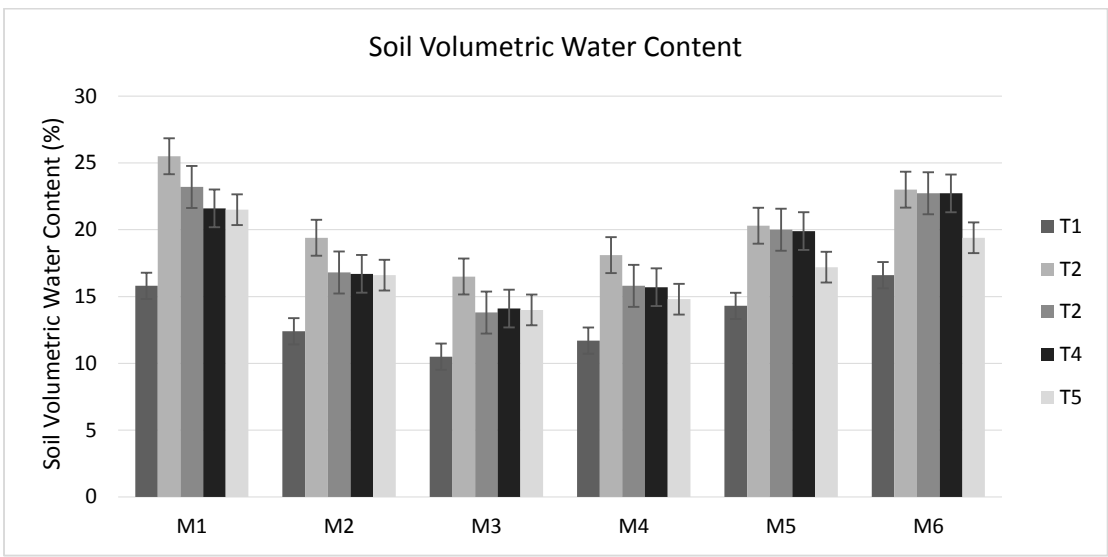

Figure 3. Influence of biochar and sewage sludge on soil volumetric water content.

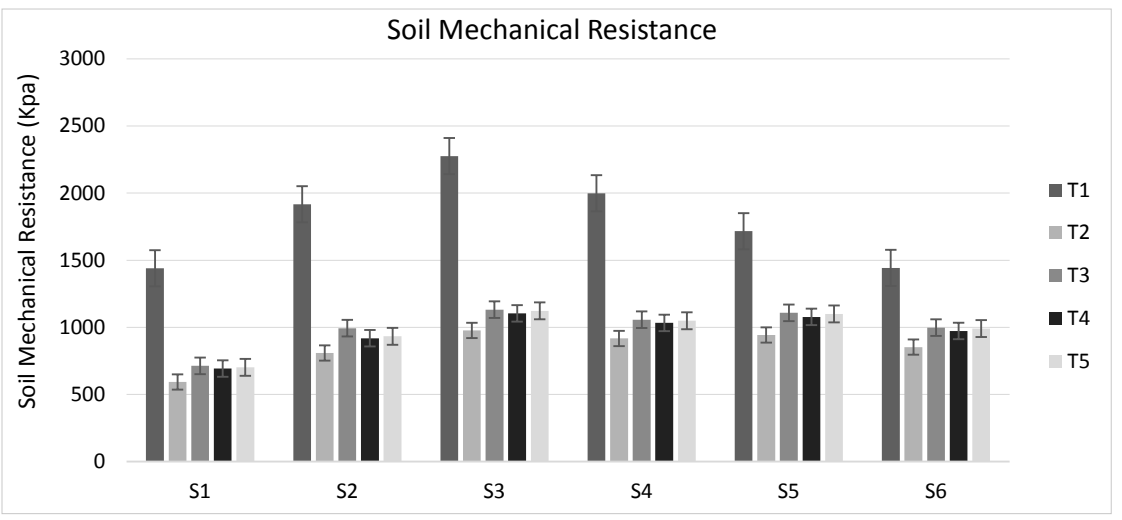

Figure 4. Influence of biochar and sewage sludge on soil mechanical resistance.

mechanical resistance with the addition of biochar (49), and Mukherjee and Lal also noted a decrease in soil mechanical resistance with the incorporation of $\mathrm{OM}$ to the soil (50). Furthermore, soil mechanical resistance rates among sub-treatments were not different. Yao et al showed that the application of biochar can improve the physical qualities of soil in terms of bulk density, soil mechanical resistance, and water holding capacity (51). Decreases in soil mechanical resistance could be attributed to the amelioration of the aggregation and the decrease in bulk density (51).

Effects of treatment applications on post-cropping soil chemical analysis

This study demonstrated that the addition of mulch sewage sludge (T4) and incorporation sewage sludge (T5) as well as their biochars (T2 and T3) increased total soil nitrogen (TN) compared to the control (T1) due to the high content of $\mathrm{N}$ in sewage sludge. Lehman and Joseph reported an increase in TN with the addition of sewage sludge (9). The sewage sludge treatments (T4 and T5) showed a higher increase in TN compared to the biochar treatments (T2 and T3). TN contents of biochar were lower than those of sewage sludge, which could be attributed to the volatilization of $\mathrm{N}$ within pyrolysis. $\mathrm{N}$ can be removed through the losses of $\mathrm{NH}_{4}-\mathrm{N}$ and $\mathrm{NO}_{3}-\mathrm{N}$ fractions, like volatile matter containing $\mathrm{N}$ groups, at $200^{\circ} \mathrm{C}(9,39)$. Some researchers showed that the application of biochar can increase the uptake and efficiency of $\mathrm{N}$ fertilizers in soil as a result of reducing $\mathrm{N}$ leaching and also by affecting the soil $\mathrm{N}$ cycle (52). The results of this study showed that the addition of $\mathrm{N}$ chemical fertilizer to soil can significantly increase TN compared to the control plot.

The results of the addition of mulch sewage sludge (T4) and incorporated sewage sludge (T5) as well as their biochars (T2 and T3) increased the available phosphorus in soil compared to the control (T1). Lehman and Joseph reported an increase in soil phosphorus with the addition of sewage sludge (9). Several studies reported an increase in AP after the application of biochar (53-55). The biochar treatments (T2 and T3) showed a higher increase in soil phosphorus compared to the sewage sludge treatments (T4 and T5). Biochar can increase nutrient pools in soil due to its high surface area and can increase essential nutrient contents in soil. Furthermore, the results of this study showed that the addition of NP (ST3) and NPK(ST5) chemical fertilizer in soil can increase soil phosphorus significantly compared to the NK (ST4), N (ST2), and control (ST1) plots (Tables 7 and 8).

The effects of treatments on the AK of soil were significant. The results showed that the addition of mulch sewage sludge (T4) and incorporated sewage sludge (T5) as well 
Table 7. Effects of treatment applications on post-cropping soil chemical analysis

\begin{tabular}{lccc}
\hline Treatment & $\mathbf{N}(\%)$ & $\mathbf{P}\left(\mathbf{m g ~ k g}^{-1}\right)$ & $\mathbf{K}\left(\mathbf{m g ~ k g}^{-1}\right)$ \\
\hline \multicolumn{4}{c}{ Factor (A) } \\
\hline Control (T1) & $0.106^{\mathrm{c}}$ & $11.4^{\mathrm{c}}$ & $390.3^{\mathrm{c}}$ \\
Biochar mulch (T2) & $0.118^{\mathrm{b}}$ & $23.5^{\mathrm{a}}$ & $466.6^{\mathrm{a}}$ \\
Biochar incorporation (T3) & $0.116^{\mathrm{b}}$ & $23.69^{\mathrm{a}}$ & $443^{\mathrm{b}}$ \\
Sewage sludge mulch (T4) & $0.158^{\mathrm{a}}$ & $16.9^{\mathrm{b}}$ & $466.5^{\mathrm{a}}$ \\
Sewage sludge incorporation (T5) & $0.155^{\mathrm{a}}$ & $16.5^{\mathrm{b}}$ & $455.5^{\mathrm{a}}$ \\
\hline \multicolumn{4}{c}{ Factor (B) } \\
\hline NPK (ST5) & $0.125^{\mathrm{bc}}$ & $22.9^{\mathrm{a}}$ & $468.6^{\mathrm{a}}$ \\
NK (ST4) & $0.143^{\mathrm{a}}$ & $15.05^{\mathrm{b}}$ & $472.8^{\mathrm{a}}$ \\
NP (ST3) & $0.142^{\mathrm{a}}$ & $22.72^{\mathrm{a}}$ & $434.2^{\mathrm{b}}$ \\
N (ST2) & $0.129^{\mathrm{ab}}$ & $15.57^{\mathrm{b}}$ & $426.5^{\mathrm{b}}$ \\
Control (ST1) & $0.113^{\mathrm{c}}$ & $15.9^{\mathrm{b}}$ & $420^{\mathrm{b}}$ \\
\hline
\end{tabular}

Table 8. Analysis of variance post-cropping soil chemical analysis

\begin{tabular}{llccc}
\hline \multirow{2}{*}{$\begin{array}{l}\text { Sources of } \\
\text { variances }\end{array}$} & \multirow{2}{*}{$\boldsymbol{d f}$} & \multicolumn{3}{c}{ Means of squares } \\
\cline { 3 - 5 } & & $\mathbf{N}$ & $\mathbf{P}$ & $\mathbf{K}$ \\
\hline Replications & 2 & 0.00030 & 1.81 & 375.8 \\
$\begin{array}{l}\text { Factor A (biochar } \\
\text { and sewage sludge) }\end{array}$ & 4 & $0.0088^{* *}$ & $408.44^{* *}$ & $15129.6^{* *}$ \\
Error A & 8 & 0.00013 & 2.59 & 186.18 \\
Factor B (chemical & 4 & $0.0022^{* *}$ & $241.8^{* *}$ & $9039.5^{* *}$ \\
fertilizer) & & & & \\
Error B & - & 0.0039 & 2.58 & 383 \\
A $\times$ B & 16 & 0.000061 & 1.44 & 70.53 \\
CV & - & 15.26 & 8.7 & 4.4 \\
\hline
\end{tabular}

**Significant at the 0.01 level; *Significant at the 0.05 level.

as their biochars (T2 and T3) increased soil AK compared to the control (T1). The sewage sludge treatments (T4 and T5) showed higher increases in soil AK compared to the biochar treatments (T2 and T3). Bierdman and Harpole reported an increase in soil AK with the addition of biochar (56). In addition, the results of this study showed that the addition of NK (ST4) and NPK (ST5) chemical fertilizer in soil can increase soil AK significantly $(P<$ 0.05) compared to the NP (ST3), N (ST2), and control (ST1) plots (Tables 7 and 8).

TN, soil available $\mathrm{P}$, and soil AK were higher with mulch treatments (T2 and T4) than the incorporation treatments (T3 and T5) (Tables 7 and 8). Some researchers have found that biochar applications can result in increased contents of total, extractable, and/or exchangeable soil nutrients (56-60).

Effect of biochar and sewage sludge applications on shoot nutrient concentration

This study demonstrated that the addition of mulch sewage sludge (T4) and incorporation sewage sludge (T5) as well as their biochars (T2 and T3) increased N concentration in shoots compared to the control (T1). The sewage sludge treatments (T4 and T5) showed higher increased $\mathrm{N}$ concentrations in shoots compared to the biochar treatments (T2 and T3). Results of this study showed that the addition of N (ST2, ST3, ST4, and ST5) chemical fertilizer to soil increased the $\mathrm{N}$ concentration in shoots significantly compared to the control plot (ST1)
Table 9. Effects of treatment applications on shoot nutrient concentration

\begin{tabular}{lccc}
\hline Treatment & $\mathbf{N}(\%)$ & $\mathbf{P}\left(\mathbf{m g ~ k g}^{-1}\right)$ & $\mathbf{K}\left(\mathbf{m g ~ k g}^{-1}\right)$ \\
\hline \multicolumn{4}{c}{ Factor (A) } \\
\hline Control (T1) & $2.08^{\mathrm{c}}$ & $0.17^{\mathrm{c}}$ & $1.18^{\mathrm{d}}$ \\
Biochar mulch (T2) & $3.86^{\mathrm{b}}$ & $0.46^{\mathrm{a}}$ & $2.34^{\mathrm{b}}$ \\
Biochar incorporation (T3) & $3.76^{\mathrm{b}}$ & $0.45^{\mathrm{a}}$ & $2.27^{\mathrm{c}}$ \\
Sewage sludge mulch (T4) & $4.57^{\mathrm{a}}$ & $0.34^{\mathrm{b}}$ & $2.4^{\mathrm{a}}$ \\
Sewage sludge incorporation (T5) & $4.38^{\mathrm{a}}$ & $0.32^{\mathrm{b}}$ & $2.34^{\mathrm{b}}$ \\
\hline \multicolumn{4}{c}{ Factor (B) } \\
\hline NPK (ST5) & $3.83^{\mathrm{b}}$ & $0.409^{\mathrm{a}}$ & $2.51^{\mathrm{a}}$ \\
NK (ST4) & $4.06^{\mathrm{a}}$ & $0.298^{\mathrm{b}}$ & $2.54^{\mathrm{a}}$ \\
NP (ST3) & $3.82^{\mathrm{b}}$ & $0.428^{\mathrm{a}}$ & $1.83^{\mathrm{b}}$ \\
N (ST2) & $4.05^{\mathrm{a}}$ & $0.319^{\mathrm{b}}$ & $1.84^{\mathrm{b}}$ \\
Control (ST1) & $2.89^{\mathrm{c}}$ & $0.304^{\mathrm{b}}$ & $1.81^{\mathrm{b}}$ \\
\hline
\end{tabular}

Table 10. Analysis of variance for shoot nutrient concentration

\begin{tabular}{llccc}
\hline \multirow{2}{*}{$\begin{array}{l}\text { Sources of } \\
\text { variances }\end{array}$} & $d f$ & \multicolumn{3}{c}{ Means of squares } \\
\cline { 3 - 5 } & & $\mathbf{N}$ & $\mathbf{P}$ & $\mathbf{K}$ \\
\hline Replications & 2 & 0.083 & 0.0021 & 0.066 \\
Factor A (biochar & 4 & $14.6^{* *}$ & $0.212^{* *}$ & $4.05^{* *}$ \\
$\begin{array}{l}\text { and sewage sludge) } \\
\text { Error A }\end{array}$ & 8 & 0.1 & 0.0019 & 0.0046 \\
Factor B (chemical & 4 & $3.47^{* *}$ & $0.057^{* *}$ & $2.188^{* *}$ \\
fertilizer) & & & & \\
Error B & - & 0.04 & 0.0017 & 0.0192 \\
A $\times$ B & 16 & 0.047 & 0.00212 & 0.0168 \\
CV & - & 5.38 & 11.84 & 6.5 \\
\hline
\end{tabular}

**Significant at the 0.01 level; *Significant at the 0.05 level.

(Tables 9 and 10). Chan et al and Taghizadeh-Toosi et al reported similar effects for biochar on $\mathrm{N}$ uptake. One way biochar may affect soil nutrients is by reducing leaching losses $(54,55)$. Nutrients can be adsorbed to biochar's surface, which slows leaching $(11,61)$.

According to the results of the present study, $\mathrm{P}$ concentration in shoots was significantly increased by the application of mulch sewage sludge (T4) and incorporation sewage sludge (T5) as well as their biochars (T2 and T3) compared to the control (T1). The biochar treatments (T2 and T3) showed higher increased P concentration in shoots compared to the sewage sludge treatments (T4 and T5). The results of this study showed that the addition of PN (ST3) and NPK (ST5) chemical fertilizers to soil can increase the $\mathrm{P}$ concentration in shoots significantly compared to the NK (ST4), N (ST2), and control plots (ST1) (Tables 9 and 10). Lehmann and Rondon indicated an increase in $\mathrm{P}$ concentration in plants with the application of biochar (62). The increase in $\mathrm{P}$ concentration as a consequence of the application of biochar may be attributed to the high $\mathrm{P}$ content in sewage sludge biochar. The highest soil P concentration was seen in biochar-amended soils (Table 4).

Potassium concentration in shoots was also significantly increased by the addition of mulch sewage sludge (T4) and incorporation sewage sludge (T5) as well as their biochars (T2 and T3) compared to the control (T1). The sewage sludge treatments (T4 and T5) showed higher increases in $\mathrm{K}$ concentration in shoots than the biochar treatments 
(T2 and T3). Moreover, the addition of NK (ST4) and NPK (ST5) chemical fertilizers to soil increased the K concentration in shoots significantly compared to the NP (ST3), N (ST2), and control plots (ST1) (Tables 9 and 10). Van Zwieten et al reported an increase in concentration of plant $\mathrm{K}$ with the addition of biochar (63). The adhesion of soil colloidal particles to each other depends upon the net attractive forces between them, called soil aggregation. This property is very important for soil structure. Soil with a good structure provides favorable conditions for the movement of water and nutrients and their absorption by plants (64).

\section{Biochar cost estimates and correlations}

The costs related to biochar depend on various parameters, e.g., the cost of the feedstock, feedstock collection and transportation, production technology and temperature, production scale, distribution and handling. The difference in costs to produce biochar depends on raw materials like green waste, poultry litter, and wastewater sewage. Lehmann and Rondon presented an estimate of $\$ 50-200 /$ ton of biochar (62). The cost of biochars produced from sewage sludge is negligible, as currently these wastes generally have a cost associated with their exposure. Results of the current study indicated that production costs may be as low as $\$ 40 /$ ton. Correlations between biological yield and $\mathrm{K}$ concentration in shoots, $\mathrm{P}$ concentration in shoots, $\mathrm{N}$ concentration in shoots, mechanical resistance at 6 times $(S 1, S 2, \ldots, S 6)$, and volumetric water contents at 6 times (M1, M2,.., M6) were obtained. A significant positive correlation with biological yield was observed in $\mathrm{K}$ concentration in shoots $(P<0.0001,0.84)$, $\mathrm{P}$ concentration in shoots $(P<0.0001$, $0.81), \mathrm{N}$ concentration in shoots $(P<0.0001,0.74)$ and volumetric water contents $(\mathrm{M} 2)(P<0.0001,0.72)$. Soils with high SSA and fine clay particles have significant effects on mechanical resistance to the root growth by cementing different sizes of soil particles. Dry bulk density and soil water content can control the soil mechanical resistance (64). In the sub-humid climate of northern Iran, in addition to the cementing effects of high quantity fine clays in high specific surface soils, slow saturation and incomplete swelling of soils may induce greater cohesion and mechanical resistance (64). The correlation between soil $\mathrm{K}$ concentration and plant $\mathrm{K}$ uptake was not significant (65).

\section{Conclusion}

This study showed that sewage sludge and sewage sludge biochar have the potential to increase growth and yield of soybean. To-date, research has clearly demonstrated that biochar improves plant productivity and yield and soil fertility through several mechanisms. Physical aspects change with biochar, which can improve soil water-holding capacity. The biochar physical structure, its high porosity, and the initial associated high surface area result in soil fertility advantages over the direct addition of nutrients. Biochar applications can also increase nutrient retention and availability. This study also found that plant tissue $\mathrm{K}$, $\mathrm{P}$, and $\mathrm{N}$ concentrations and soil $\mathrm{P}, \mathrm{N}$, and $\mathrm{K}$ increased with the application of biochar sewage sludge and sewage sludge. These nutrients may be directly introduced to the soil through labile organic compounds associated with biochar sewage sludge and become available as these compounds weather. This paper also reports that biochar and sewage sludge amendment had positive impacts on soil physical properties; for example, biochar and sewage sludge decreased the bulk density of the soil. Biochar and sewage sludge treatments led to increased soil water content and decreased soil mechanical resistance. Having perfect knowledge about the circumambient environment is of high priority for researchers and agriculture policy makers. In soils containing silt clay loam texture, illite minerals, and with high SSA, Heating sludge removed all pathogens. It is recommended that short- and long-term studies be conducted in the region with further increases in the rates of combined biochar and sewage sludge application to determine the optimum level of application required for optimum crop production.

\section{Acknowledgments}

This research was funded by Gorgan University of Agricultural Sciences and Natural Resources and Golestan Water and Wastewater Company (Iran).

\section{Ethical issues}

Authors report no ethical issues in the performance of this study.

\section{Competing interests}

The authors affirm that this article is their original work and that they have no conflicts of interest to declare.

\section{Author's contributions}

All authors were involved in all stages of the article. On behalf of the co-authors, the corresponding author bears full responsibility for this submission.

\section{References}

1. Shurtleff W, Aoyagi A. History of soybeans and soy foods in the Middle East; 2007. [cited 2015 June 12]. Available from: http://www.soyinfocenter.com/HSS/middle_east.php.

2. Garrity DP. Agroforestry and the achievement of the Millennium Development Goals. Agrofor Syst 2004; 61(1): 5-17.

3. Khaim S, Chowdhury MAH, Saha BK. Organic and inorganic fertilization on the yield and quality of soybean. Journal of the Bangladesh Agricultural University 2013; 11(1): 23-8. doi: 10.3329/jbau.v11i1.18199.

4. Fahiminia M, Farzadkia M, Jafari Mansoorian H, Majidi G, Mirzabeygi Arhany M, Khanjani N, et al. The status of wastewater management in Shokuhieh industrial park (A case study of Qom province). Environ Health Eng Manage J 2015; 2(4): 165-71.

5. Hwang IH, Ouchi Y, Matsuto T. Characteristics of leachate from pyrolysis residue of sewage sludge. Chemosphere 2007; 68(10): 1913-19. doi: 10.1016/j.chemosphere.2007.02.060. 
6. Domínguez A, Menéndez JA, Inguanzo $M$, Pís JJ. Production of bio-fuels by high temperature pyrolysis of sewage sludge using conventional and microwave heating. Bioresurse Technol 2006; 97(10): 1185-93. doi: 10.1016/j. biortech.2005.05.011

7. Smith KM, Fowler GD, Pullket S, Graham NJ. Sewage sludgebased adsorbents: a review of their production, properties and use in water treatment applications. Water Res 2009; 43(10): 2569-94. doi: 10.1016/j.watres.2009.02.038.

8. Hossain MK, Strezov V, Chan KY, Nelson PF. Agronomic properties of wastewater sludge biochar and bioavailability of metals in production of cherry tomato (Lycopersicon esculentum). Chemosphere 2010; 78(9): 1167-71. doi: 10.1016/j.chemosphere.2010.01.009.

9. Lehman J, Joseph S, eds. Biochar for Environmental Management: Science, Technology and Implementation. 2nd ed. London: Taylor \& Francis Ltd; 2009.

10. Verheijen F, Jeffery S, Bastos AC, van der Velde M, Diafas I. Biochar Application to Soils A Critical Scientific Review of Effects on Soil Properties, Processes and Functions. Italy: European Commission, Joint Research Centre, Institute for Environment and Sustainability; 2010.

11. Chan KY, Xu Z. Biochar nutrient properties and their enhancement. In: Lehmann J, Joseph S, eds. Biochar for Environmental Management: Science and Technology. London: Earthscan; 2009.

12. Kookana RS, Sarmah AK, Van Zwieten L, Krull E, Singh B. 3 Biochar application to soil: agronomic and environmental benefits and unintended consequences. In: Advances in Agronomy San Diego. San Diego: Elsevier; 2011. p. 103-43.

13. Zhang A, Bian R, Pan G, Cui L, Hussain Q, Li L, et al. Effects of biochar amendment on soil quality, crop yield and greenhouse gas emission in a Chinese rice paddy: a field study of 2 consecutive rice growing cycles. Field Crops Res 2012; 127: 153-160. doi:10.1016/j.fcr.2011.11.020.

14. Liu T, Liu B, Zhang W. Nutrients and heavy metals in biochar produced by sewage sludge pyrolysis: its application in soil amendment. Pol J Environ Stud 2014; 23(1): 271-5.

15. Amini S, Movahedi Naeini SA, Mashayekhi K. Effects of paper-mill sludge as a mulch versus topsoil incorporation on potassium uptake and the grain yield of rain-fed wheat in a high specific surface loess soil with illite dominance in clay fraction. Appl Environ Soil Sci 2012; 2012: 624824. doi: 10.1155/2012/624824.

16. Thomas GW, Sparks DL, Page AL, Helmke PA, Loeppert $\mathrm{RH}$, Soltanpour, et al. Soil $\mathrm{pH}$ and soil acidity. Methods of soil analysis. Part 3-chemical methods. Madison, WI: Soil Science Society of America; 1996.

17. Rhoades JD. Salinity: electrical conductivity and total dissolved solids. In: Sparks JD, Sparks DL, Page AL, Helmke PA, Loeppert RH, Soltanpour MA, et al, eds. Methods of Soil Analysis, Part 3 - Chemical Methods. Madison, WI: Soil Science Society of America; 1996. p. 417-435.

18. Sumner M E, Miller W P. Cation Exchange Capacity and Exchange Coefficients. Madison, USA: Soil Science of America and American Society Agronomy; 1996.

19. Nelson DW, Sommers L. Total Carbon, Organic Carbon, and Organic Matter. Madison, USA: ASA-SSSA; 1982.

20. Richards LA. Diagnosis and improvement of saline and alkali soils. Soil Sci 1954; 78(2): 154.

21. Olsen SR, Cole CV, Frank S,Dean LA. Estimation of Available phosphorus in Soils by Extraction with Sodium Bicarbonate. Washington DC: United States Department of
Agriculture; 1954.

22. Bouyoucos GJ. Hydrometer method improved for making particle size analyses of soils. Agron J 1962; 54(5): 464-5. doi:10.2134/agronj1962.00021962005400050028x.

23. Lu H, Zhang W, Wang S, Zhuang L, Yang Y, Qiu R. Characterization of sewage sludge-derived biochars from different feedstocks and pyrolysis temperatures. J Anal Appl Pyrolysis 2013; 102: 137-43.

24. Méndez A, Terradillos M, Gascó G. Physicochemical and agronomic properties of biochar from sewage sludge pyrolysed at different temperatures. J Anal Appl Pyrolysis 2013; 102: 124-30. doi: 10.1016/j.jaap.2013.03.006.

25. Yuan JH, Xu RK, Zhang $H$. The forms of alkalis in the biochar produced from crop residues at different temperatures. Bioresour Technol 2011; 102(3): 3488-97. doi: $\quad$ 10.1016/j.biortech.2010.11.018.

26. Mukome FN, Zhang X, Silva LC, Six J, Parikh SJ. Use of chemical and physical characteristics to investigate trends in biochar feedstocks. J Agric Food Chem 2013; 61(9): 2196-204. doi: 10.1021/jf3049142.

27. De Jonge LW, Moldrup P, Jacobsen OH. Soil-water content dependency of water repellency in soils. Soil Sci 2007; 172(8): 577-88. doi: 10.1097/SS.0b013e318065c090.

28. American Society for Testing and Materials International (ASTM International). Standard Test Methods for Laboratory Determination of Water (Moisture) Content of Soil and Rock by Mass/ASTM D2216 - 10. Philadelphia: ASTM International; 2010. doi: 10.1520/D2216-10.

29. Tessier A, Campbell PG, Bisson M. Sequential extraction procedure for the speciation of particulate trace metals. Anal Chem 1979; 51(7): 844-51. doi: 10.1021/ac50043a017.

30. Westerman RL. Soil Testing and Plant Analysis. Madison,Wis, USA: Soil Science Society of America; 2005.

31. Zielińska A, Oleszczuk P, Charmas B, Skubiszewska-Zięba J, Pasieczna-Patkowska S. Effect of sewage sludge properties on the biochar characteristic. J Anal Appl Pyrolysis 2015; 112: 201-213. doi: 10.1016/j.jaap.2015.01.025.

32. Oh TK, Choi B, Shinogi Y, Chikushi J. Characterization of biochar derived from three types of biomass. Journal of the Faculty of Agriculture, Kyushu University 2012; 57(1): 61-6.

33. Song XD, Xue XY, Chen DZ, He PJ, Dai XH. Application of biochar from sewage sludge to plant cultivation: influence of pyrolysis temperature and biochar-to-soil ratio on yield and heavy metal accumulation. Chemosphere 2014; 109: 213-20. doi: 10.1016/j.chemosphere.2014.01.070.

34. Lester JN, Sterritt RM, Kirk PWW. Significance and behavior of heavy metals in waste water treatment processes II. Sludge treatment and disposal. Sci Total Environ 1983; 30: 45-83. doi: 10.1016/0048-9697(83)90003-7.

35. US EPA. Standards for the use or disposal of sewage sludge. Federal Register 1993; 58(32):9248-415.

36. Agrafioti E, Bouras G, Kalderis D, Diamadopoulos E. Biochar production by sewage sludge pyrolysis. J Anal Appl Pyrolysis 2013; 101: 72-78. doi: 10.1016/j.jaap.2013.02.010.

37. Shinogi Y, Yoshida H, Koizumi T, Yamaoka M, Saito T. Basic characteristics of low-temperature carbon products from waste sludge. Adv Environ Res 2003; 7(3): 661-665.

38. Gaskin JW, Steiner C, Harris K, Das KC, Bibens B. Effect of low-temperature pyrolysis conditions on biochar for agricultural use. Transactions of the Asabe 2008; 51(6): 2061-9.

39. Agboola K, Moses SA. Effect of biochar and cowdung on nodulation, growth and yield of soybean (Glycine max L. 
Merrill). Int J Agric Biosci 2015; 4(4): 154-60.

40. Yamika WSD, Ikawati KR. Combination inorganic and organic fertilizer increased yield production of soybean in rain-field Malang, Indonesia. American-Eurasian Journal of Sustainable Agriculture 2012; 6(1): 14-17.

41. Yooyen J, Wijitkosum S, Sriburi T. Increasing yield of soybean by adding biochar. J Environ Res Dev 2015; 9(4): 1066-74.

42. Navin K, Singh VK, Thakur RB, Kumar N. Effect of level and time of $\mathrm{N}$ application on the performance of winter rice. J Appl Biol 1996; 6(1-2): 48-53.

43. Falodun EJ, Osaigbovo AU, Remison SU. The effect of packaged organic and inorganic fertilizers on the growth and yield of soyabean (Glycine max). African Journal of General Agriculture 2010; 6(3): 169-75.

44. Liang B, Lehmann J, Solomon D, Kinyangi J, Grossman J, O'neill B, et al . Black carbon increases cation exchange capacity in soils. Soil Sci Soc Am J 2006; 70(5): 1719-1730.

45. MacRae RJ, Mehuys GR. The effect of green manuring on the physical properties of temperate-area soils. In: Stewart BA, ed. Advances in Soil Science. New York: Springer; 1985. p. 71-94.

46. Jones DL, Edwards-Jones G, Murphy DV. Biochar mediated alterations in herbicide breakdown and leaching in soil. Soil Biol Biochem 2011; 43(4): 804-13. doi: 10.1016/j. soilbio.2010.12.015.

47. Asai H, Samson BK, Stephan HM, Songyikhangsuthor K, Homma K, Kiyono Y, et al. Biochar amendment techniques for upland rice production in Northern Laos: 1 . Soil physical properties, leaf SPAD and grain yield. Field Crops Res 2009; 111(1-2): 81-4. doi: 10.1016/j.fcr.2008.10.008.

48. Chan KY, Van Zwieten L, Meszaros I, Downie A, Joseph S. Agronomic values of greenwaste biochar as a soil amendment. Australian Journal of Soil Research 2008; 45(8): 629-34.

49. Gantzer CJ, Buyanovsky GA, Alberts EE, Remley PA. Effects of soybean and corn residue decomposition on soil strength and splash detachment. Soil Sci Soc Am J 1987; 51(1): 2026. doi: 10.2136/sssaj1987.03615995005100010042x.

50. Mukherjee A, Lal R. Biochar impacts on soil physical properties and greenhouse gas emissions. Agronomy 2013; 3(2): 313-39. doi: 10.3390/agronomy3020313.

51. Yao $Y$, Gao B, Zhang $M$, Inyang $M$, Zimmerman AR. Effect of biochar amendment on sorption and leaching of nitrate, ammonium, and phosphate in a sandy soil. Chemosphere 2012; 89(11): 1467-71. doi: 10.1016/j. chemosphere.2012.06.002.

52. Nigussie A, Kissi E, Misganaw M, Ambaw G. Effect of biochar application on soil properties and nutrient uptake of lettuces (Lactuca sativa) grown in chromium polluted soils. American-Eurasian Journal of Agriculture and Environmental Science 2012; 12(3): 369-76.

53. Van Zwieten L, Kimber S, Morris S, Chan KY, Downie A, Rust J, et al. Effects of biochar from slow pyrolysis of papermill waste on agronomic performance and soil fertility. Plant Soil 2010; 327(1-2): 235-46.

54. Zwieten Van L, Kimber S, Morris S, Chan KY, Downie A, Rust J. Effects of biochar from slow pyrolysis of papermill waste on agronomic performance and soil fertility. Plant Soil 2010; 327(1-2): 235-46.

55. Taghizadeh-Toosi A, Clough TJ, Sherlock RR, Condron, LM. Biochar adsorbed ammonia is bioavailable. Plant Soil 2012; 350(1-2): 57-69. doi: 10.1007/s11104-011-0870-3.

56. Biederman LA, Harpole WS. Biochar and its effects on plant productivity and nutrient cycling: a meta-analysis. GCB Bioenergy 2013; 5(2): 202-14. doi:10.1111/gcbb.12037.

57. Dempster DN, Gleeson DB, Solaiman Z, Jones DL, Murphy DV. Decreased soil microbial biomass and nitrogen mineralisation with eucalyptus biochar addition to a coarse textured soil. Plant Soil 2012; 354(1-2): 311-24. doi: 10.1007/s11104-011-1067-5.

58. Dempster DN, Jones DL, Murphy DV. Organic nitrogen mineralization in two contrasting agro-ecosystems is unchanged by biochar addition. Soil Biol Biochem 2012; 48: 47-50. doi: 10.1016/j.soilbio.2012.01.013.

59. Nelson NO, Agudelo SC, Yuan W, Gan J. Nitrogen and phosphorus availability in biochar-amended soils. Soil Sci 2011; 176(5): 218-26. doi: 10.1097/SS.0b013e3182171eac.

60. Beck DA, Johnson GR, Spolek GA. Amending greenroof soil with biochar to affect runoff water quantity and quality. Environ Pollut 2011; 159(8-9): 2111-8. doi: 10.1016/j. envpol.2011.01.022.

61. Lehmann J. A handful of carbon. Nature 2007; 447(7141): 143-4. doi: 10.1038/447143a.

62. Lehmann J, Rondon M. Bio-char soil management on highly weathered soils in the humid tropics. In: Uphoff N, ed. Biological Approaches to Sustainable Soil Systems. Boca Raton, FL: CRC Press; 2006. p. 517-30.

63. Van Zwieten L, Meszaros I, Downie A, Chan YK, Joseph S. Soil health: can the cane industry use a bit of 'black magic'. Aust Canegrower 2008; 17: 10-11.

64. Borselli L, Carnicelli S, Ferrari GA, Pagliai M, Lucamante G. Effect of gypsum on hydrological, mechanical and porosity properties of a kaolinitic crusting soil. Soil Technol 1996; 9(1-2): 39-54. doi: 10.1016/0933-3630(95)00034-8.

65. Amini S, Movahedi Naeini SAR. Effects of paper mill sludge application on physical properties of an illitic loess slowly swelling soil with high specific surface area and wheat yield in a temperate climate. J Agric Sci 2013; 5(1): 295-313. doi: $10.5539 /$ jas.v5n1p295. 